\title{
GAMBARAN KINERJA PENGELOLA DI PUSKESMAS KOTA JAMBI
}

\author{
Haflin, Andy Brata* \\ Jurusan Farmasi Poltekkes Kemenkes Jambi \\ *Korespondensi penulis : andybrata@poltekkesjambi.ac.id
}

\begin{abstract}
ABSTRAK
Latar Belakang : Pelayanan kefarmasian pada saat ini telah berubah paradigmanya dari orientasi obat kepada pasien hingga sekarang yang mengacu pada asuhan kefarmasian (Pharmaceutical Care). Sebagai konsekuensinya, Apoteker sebagai tenaga farmasi dituntut untuk meningkatkan pengetahuan, keterampilan dan perilaku agar dapat berinteraksi langsung dengan pasien, yang meliputi pengelolaan sediaan farmasi dan bahan medis habis pakai serta pelayanan farmasi klinik dengan memanfaatkan tenaga, dana, prasarana, sarana dan metode tatalaksana yang sesuai dalam upaya mencapai tujuan yang ditetapkan. Penelitian ini bertujuan untuk mengetahui kinerja pengelola obat di Puskesmas Kota Jambi menurut kriteria Permenkes No. 74 Tahun 2016.

Metode: Jenis penelitian ini adalah penelitian penjelasan (Explanatory research), yang dilakukan pada petugas pengelola obat yang bekerja di Puskesmas Kota Jambi. Sampel ditentukan 20 orang petugas pengelola obat, yang dipilih secara total sampling Data dikumpulkan dengan cara menyebar kuesioner untuk menilai kinerja yang dilakukan oleh petugas pengelola obat terhadap pengelolaan obat di Puskesmas di Kota Jambi. Variabel penelitian adalah kinerja pengelola obat di Puskesmas yang indikatornya berupa masa kerja, komitmen pemimpin, pengetahuan yang dimiliki pengelola obat. Data selanjutnya dianalisa dengan Regresi Linier Berganda..

Hasil : Penelitian menunjukkan secara simultan ketiga dimensi pengelolaan obat berpengaruh signifikan terhadap kinerja pengelola obat; sementara secara parsial satu variabel (komitmen pemimpin) memiliki pengaruh signifikan $(\mathrm{p}<0,05)$, sedangkan variabel masa kerja dan pengetahuan tidak memiliki pengaruh yang signifikan. Kinerja pengelola obat di Puskesmas Kota Jambi tidak dipengaruhi oleh masa kerja dan pengetahuan petugas pengelola obat.
\end{abstract} Kesimpulan: Kinerja pengelola obat dipengaruhi oleh komitmen pemimpin.

Kata kunci: masa kerja; komitmen pemimpin; pengetahuan; kinerja pengelola obat.

\section{OVERVIEW OF MANAGING PERFORMANCE AT THE JAMBI CITY HEALTH CENTER}

\section{ABSTRACT}

Background: Pharmaceutical services at this time have changed their paradigm from drug to patients orientation, which refers to pharmaceutical care. As a consequence, pharmacists are required to improve their knowledge, skills and behavior so that they can interact directly with patients. Pharmaceutical services include the management of pharmaceutical preparations and medical consumables and clinical pharmacy services by utilizing personnel, funds, infrastructure, facilities and appropriate management methods in an effort to achieve the stated goals. The purpose of the study was conducted to determine the performance of drug managers in Jambi City Health Center according to Public Health Centre No. criteria. 74 of 2016.

Method: The type of research used was explanatory research, conducted on drug management officers who work at the Jambi City Health Center. The sample was determined 20 drug management officers, selected by total sampling. Data was collected by distributing questionnaires to assess the performance of drug management officers on drug management at the Public Health Centre in Jambi City. The research variable was the performance of the drug manager in the Public Health Centre, the indicators of which are years of service, the commitment of the leaders, the knowledge possessed by the drug manager. The data then analyzed using Multiple Linear Regression technique.

Results: The study showed that simultaneously the three dimensions of drug management had a significant effect on the performance of drug management; while partially one variable (leader commitment) has a significant effect ( $p$ $<0.05)$, while the tenure and knowledge variables do not have a significant effect. The performance of drug management in the Jambi City Health Center is not affected by the years of service and knowledge of drug management officers.

Conclusion: The performance of drug management was influenced by the commitment of the leader.

Keywords: working period; commitment of the leade; knowledge; performance of drug management. 


\section{PENDAHULUAN}

Puskesmas adalah Unit Pelaksana Teknis Dinas Kesehatan Kabupaten/Kota yang bertanggung jawab menyelenggarakan pembangunan kesehatan di suatu wilayah kerja. ${ }^{1,2,3}$ Secara nasional standar wilayah kerja Puskesmas adalah satu kecamatan. Apabila di satu kecamatan terdapat lebih dari satu Puskesmas, maka tanggung jawab wilayah kerja dibagi antar Puskesmas dengan memperhatikan keutuhan konsep wilayah yaitu desa/ kelurahan atau dusun/rukun warga. Pelayanan kefarmasian pada saat ini telah berubah paradigmanya dari orientasi obat kepada pasien hingga sekarang yang mengacu pada asuhan kefarmasian (Pharmaceutical Care). Sebagai konsekuensi perubahan orientasi tersebut, Apoteker sebagai tenaga farmasi dituntut untuk meningkatkan pengetahuan, keterampilan dan perilaku agar dapat berinteraksi langsung dengan pasien, yang meliputi pengelolaan sediaan farmasi dan bahan medis habis pakai serta pelayanan farmasi klinik dengan memanfaatkan tenaga, dana, prasarana, sarana dan metode tatalaksana yang sesuai dalam upaya mencapai tujuan yang ditetapkan.,3 Pengelolaan obat adalah suatu rangkaian kegiatan yang menyangkut aspek perencanaan, pengadaan, distribusi dan penggunaan obat dengan memanfaatkan sumber-sumber yang ada. ${ }^{4}$ Pengelolaan obat merupakan hal yang sangat penting dalam mendukung pelaksanaan sistem pelayanan kesehatan di tingkat Kabupaten/Kota, selain itu pengelolaan obat juga merupakan salah satu pendukung penting dalam pelayanan kesehatan dasar di Puskesmas, oleh karena itu pengembangan dan penyempurnaan pengelolaan obat di Kabupaten/Kota harus dilakukan secara terus menerus. Hal ini perlu dilakukan agar dapat mendukung pelayanan kesehatan dasar yang merupakan kebutuhan masyarakat yang semakin meningkat, sehingga terjamin ketersediaannya dalam jumlah dan jenis yang cukup sesuai dengan kebutuhan pola penyakit, tepat waktu, merata dan berkesinambingan. Ini juga penting kiranya melihat kinerja pengelola obat yang berkontribusi langsung terhadap pelayanan di Puskesmas dalam rangka mewujudkan visi dan misi Puskesmas untuk pembangunan kesehatan di Kota Jambi.

Penelitian 5 menyimpulkan bahwa pelatihan indikator evaluasi pengelolaan dan pembiayaan obat terhadap tenaga pengelola obat menunjukkan peningkatan pengetahuan secara bermakna pada pelatihan pertama dan pelatihan kedua. Peningkatan pengetahuan tenaga pengelola obat yang berpendidikan tinggi lebih baik dari pada petugas yang berpendidikan rendah. Sesuai penelitian ${ }^{6}$, bahwa perlu melakukan supervisi secara berkala terhadap pengelolaan logistik obat termasuk kepatuhan petugas kepada pedoman pengobatan. Penelitian ${ }^{7}$, menunjukkan salah satu upaya meningkatkan kinerja petugas di rumah sakit adalah dengan memberikan imbalan sesuai dengan beban kerja yang dilakukannya. Penelitian ${ }^{8}$, menyimpulkan mekanisme pengelolaan obat di puskesmas perlu dirubah agar obat rutin dan program tersentralisir pada satu unit pengelola obat sehingga semua obat bisa tercatat dan terlaporkan dengan baik.

Kinerja adalah penampilan hasil karya personal suatu organisasi. ${ }^{9}$ Kajian-kajian tentang kinerja memberikan kejelasan tentang faktorfaktor yang berpengaruh terhadap kinerja personal. ${ }^{9}$ Ada beberapa faktor yang langsung berkaitan dengan kinerja seorang dokter Puskesmas yaitu penghasilan, manfaat supervisi, pengembangan karier, pelatihan dan seks. Dengan kata lain bahwa faktor-faktor tersebut bisa meningkatkan kinerja personal dan organisasi. ${ }^{10}$ Pada penelitian faktor-faktor yang berhubungan dengan kinerja petugas pengisi formulir LPLPO Puskesmas di Kabupaten Karawang tahun 1977, disimpulkan kinerja petugas LPLPO berhubungan dengan tingkat pendidikan kepuasan kerja dan waktu yang disediakan. ${ }^{11}$ Lalu dalam pengelolaan LPLPO dan faktor-faktor yang berhubungan dengan kinerja petugas pengelola obat Puskesmas dalam mengelola LPLPO di Kabupaten Padang Pariaman dan Agam Provinsi Sumatra Barat, tahun 2000 disimpulkan bahwa hari kerja, pendidikan, dan pelatihan mempengaruhi kinerja pengelola obat Puskesmas di Kabupaten Padang Pariaman dan di Kabupaten Agam Provinsi Sumatera Barat. $^{12}$ Seterusnya pada penelitian faktor-faktor yang mempengaruhi kualitas LPLPO yang disampaikan pengelola LPLPO seKabupaten Kapuas Hulu bahwa ada hubungan yang bermakna antara pendidikan, pengetahuan, motivasi dan waktu pengisian LPLPO dengan kualitas LPLPO. ${ }^{13}$

Dari beberapa hasil penelitian dan teori yang dikemukakan dapat dirangkum bahwa kinerja berhubungan dengan motivasi, jabatan, pelatihan, supervisi, pengelolaan, pendidikan, pengetahuan, masa kerja dan tersedianya peralatan dalam melaksanakan tugas.

Pelayanan kefarmasian meliputi pengelolaan sumber daya (SDM, sarana prasarana, sediaan farmasi dan perbekalan kesehatan serta administrasi) dan pelayanan farmasi klinik (penerimaan resep, peracikan obat, penyerahan obat, informasi obat dan pencatatan/penyimpanan resep) dengan memanfaatkan tenaga, dana, prasarana, sarana dan metode tatalaksana yang sesuai dalam upaya mencapai tujuan yang ditetapkan. Oleh karena itu, penting kiranya 
melihat kinerja pengelola obat yang berkontribusi langsung terhadap pelayanan di Puskesmas dalam rangka mewujudkan visi dan misi Puskesmas untuk pembangunan kesehatan di Kota Jambi. ${ }^{2,3}$

Berdasarkan masalah diatas perlu dilakukan penelitian untuk melihat kinerja pengelola obat di Puskesmas Kota Jambi menurut kriteria Permenkes No. 74 Tahun 2016.

\section{METODE}

Penelitian ini adalah penelitian penjelasan (Explanatory research) yang akan membuktikan hubungan kausal antara variabel bebas dan variabel terikat yang dilakukan pada petugas pengelola obat yang bekerja di Puskesmas Kota Jambi sebanyak 20 buah Puskesmas. Data dikumpulkan dengan cara menyebar kuesioner menilai kinerja yang dilakukan oleh petugas pengelola obat terhadap pengelolaan obat di Puskesmas di Kota Jambi.

Variabel penelitian adalah kinerja pengelola obat di Puskesmas yang indikatornya berupa masa kerja, komitmen pemimpin, pengetahuan yang dimiliki pengelola obat. Data selanjutnya dianalisa dengan menghitung hasil kinerja dan faktor faktor yang mempengaruhi dengan statistik teknik Regresi Linier Berganda. Tujuan penelitian dilakukan untuk mengetahui kinerja pengelola obat di Puskesmas Kota Jambi menurut kriteria Permenkes No. 74 Tahun 2016. Total sampel ditentukan sebanyak 20 orang petugas pengelola obat, yang dipilih secara total sampling.

\section{HASIL DAN PEMBAHASAN}

Tabel 1. Distribusi Frekuensi Karakteristik Responden

\begin{tabular}{ll}
\hline Karakteristik & Jumlah \\
\hline Puskesmas & 20 \\
Tingkat Pendidikan Tenaga Farmasi & \\
Apoteker & 8 \\
S1 Farmasi & 10 \\
D3 Farmasi & 2 \\
\hline
\end{tabular}

Hasil penelitian menunjukkan responden dari 20 Puskesmas di Kota Jambi, Petugas Pengelola Obat yang berlatar belakang pendidikan Apoteker sebanyak 8 orang (Puskesmas Simpang Kawat, Simpang IV Sipin, Tanjung Pinang, Paal V, Talang Banjar, Rawasari, Payo Selincah dan Talang Bakung), sisanya berpendidikan S-1 Farmasi sebanyak 10 orang dan 2 orang berpendidikan D-3 Farmasi. 19 orang berjenis kelamin perempuan, 1 orang laki-laki. Lama kerja berkisar 10 - 40 tahun.

Sehingga kinerjanya sebagai petugas pengelola obat berdasarkan pengetahuan dapat diasumsikan sudah seperti yang diharapkan. Ini sejalan dengan hasil penelitian Sriana A, dkk (2002) di Provinsi Jawa Timur dan Sumatera Barat bahwa ada hubungan tingkat pendidikan dengan kemampuan pengelolaan obat. Tingkat pendidikan pengelolaan obat pada penelitian ini sudah seluruhnya yang berpendidikan farmasi dalam pengelolaan obat puskesmas di Kota Jambi, ${ }^{5}$ berbeda dengan Fitria (2018), pengelolaan obat yang terjadi di Puskesmas Kabupaten Bungo, Jambi belum baik karena belum sesuai dengan standar yang ditetapkan dalam Kemenkes RI 1411 dan kurangnya pengelola obat di Puskesmas Kabupaten Bungo, Jambi terutama tenaga Apoteker. $^{14}$

Berdasarkan hasil penelitian Purwaningsih, dkk (2003), bahwa ada beberapa cara yang dapat di tempuh pemerintah daerah dalam meningkatkan peran pengelola obat di pelayanan kesehatan yaitu dengan edukasi, manajerial dan regulasi. Cara edukasi dapat di tempuh dengan pendidikan formal atau pendidikan lanjut sehingga mampu menerapkan peraturan daftar obat Esensial Nasional (DOEN), pengadaan dan distribusi formularium dan keuangan. ${ }^{15,17,22}$

Tabel 2. Hasil Analisis Statistik Uji Parsial

\begin{tabular}{lc}
\hline Variabel & pValue \\
\hline Pengetahuan & 0,102 \\
Komitmen & 0,000 \\
Masa Kerja & 0,295 \\
\hline
\end{tabular}

Hasil penelitian menunjukkan bahwa pengetahuan responden dominan pada kategori baik selanjutnya dengan uji regresi berganda, variabel pengetahuan menunjukkan tidak ada pengaruh yang signifikan terhadap kinerja petugas pengelola obat $(p<0,05)$. Berdasarkan pencapaian tingkat pengetahuan dapat di asumsikan sudah seperti yang diharapkan dan dilihat dari jumlah petugas pengelola obat, 8 orang diantaranya sudah berpendidikan apoteker.

Jika puskesmas belum ada apotekernya, saat ini Pemerintah Kota Jambi melalui Dinas Kesehatan Kota Jambi, membuat SK penunjukkan untuk Apoteker yang menjadi Penanggungjawab di Puskesmas tersebut. Sehingga ada beberapa puskesmas dikelola oleh satu orang apoteker. Sehingga terjadi kendala dari pemerataan beban kerja pada tenaga farmasi yang membuat beban kerjanya berbeda-beda yang membuat pengelolan obat dan pelayanan farmasi klinisya tidak optimal. 15,16

Ditinjau dari segi pengetahuan pengelolaan obat di puskesmas, seluruh petugas pengelola obat (20 orang) sudah tahu mengenai pengelolaan obat di puskesmas. Peningkatan pengetahuan 
pengelolaan obat melalui Bimbingan Teknis (BIMTEK) yang dilaksanakan oleh Instalasi Farmasi Kota Jambi dan Dinas Kesehatan Kota Jambi mengenai pengelolaan obat logistik farmasi, evaluasi pemberian informasi obat (PIO) dan penggunaan obat rasional (POR). Pengadaan obat di puskesmas dilakukan melalui e-katalog dan pembelian langsung. ${ }^{15,16,17}$

Pendistribusian obat dilaksanakan berdasarkan pengeluaran obat sesuai permintaan dokter berdasarkan resep melalui tahapan perencanaan, pengadaan, pendistribusian dan penggunaan.

Perencanaan merupakan proses kegiatan seleksi Sediaan Farmasi dan Bahan Medis Habis Pakai untuk menentukan jenis dan jumlah Sediaan Farmasi dalam rangka pemenuhan kebutuhan Puskesmas. $^{3}$ Tujuan perencanaan adalah untuk mendapatkan: (1) Perkiraan jenis dan jumlah Sediaan Farmasi dan Bahan Medis Habis Pakai yang mendekati kebutuhan; (2) Meningkatkan penggunaan Obat secara rasional; dan (3) Meningkatkan efisiensi penggunaan Obat.

Perencanaan kebutuhan Sediaan Farmasi dan Bahan Medis Habis Pakai di Puskesmas setiap periode dilaksanakan oleh Ruang Farmasi di Puskesmas. ${ }^{3}$ Proses seleksi Sediaan Farmasi dan Bahan Medis Habis Pakai dilakukan dengan mempertimbangkan pola penyakit, pola konsumsi Sediaan Farmasi periode sebelumnya, data mutasi Sediaan Farmasi, dan rencana pengembangan. Proses seleksi Sediaan Farmasi dan Bahan Medis Habis Pakai juga harus mengacu pada Daftar Obat Esensial Nasional (DOEN) dan Formularium Nasional. Proses seleksi ini harus melibatkan tenaga kesehatan yang ada di Puskesmas seperti dokter, dokter gigi, bidan, dan perawat, serta pengelola program yang berkaitan dengan pengobatan. Proses perencanaan kebutuhan Sediaan Farmasi per tahun dilakukan secara berjenjang (bottom-up). Puskesmas diminta menyediakan data pemakaian Obat dengan menggunakan Laporan Pemakaian dan Lembar Permintaan Obat (LPLPO). Selanjutnya Instalasi Farmasi Kabupaten/Kota akan melakukan kompilasi dan analisa terhadap kebutuhan Sediaan Farmasi Puskesmas di wilayah kerjanya, menyesuaikan pada anggaran yang tersedia dan memperhitungkan waktu kekosongan Obat, buffer stock, serta menghindari stok berlebih. ${ }^{3}$

Kinerja pengelolaan obat di puskesmas Kota Jambi mengenai perencanaan obat melalui Rencana Kebutuhan Obat (RKO) dari masingmasing puskesmas, dan ini digabung menjadi RKOnya Instalasi Farmasi Kota Jambi. Perencanaan kebutuhan obat di puskesmas di Kota Jambi, untuk obat PKD (dari Instalasi Farmasi Kota Jambi) melalui Dinas Kesehatan
Kota Jambi setiap triwulan sekali, untuk obat dari dana BLUD setiap tahun dua kali dan untuk obat program dari Dinas Kesehatan Provinsi Jambi tergantung permintaan ke Instalasi Farmasi Provinsi Jambi. Hal ini sejalan dengan Penelitian Rismalawati (2015), Nurniati (2016), Renaldi (2017), Kobandaha F. Dkk (2016). Berbeda dengan Hasratna (2016), perencanaan kebutuhan dilakukan satu kali satu tahun dan dilaksanakan setiap akhir tahun. ${ }^{15,16,17,18,19}$

Pengadaan obat di Puskesmas Kota Jambi dilakukan setiap 3 bulan dengan membuat Laporan Pemakaian dan Lembar Permintaan Obat (LPLPO) yang telah disetujui oleh Kepala Puskesmas dengan memperhatikan jumlah, keadaan fisik dan tanggal kadaluarsa obat, ini sejalan dengan penelitian Nurniati dan Rismalawati. ${ }^{15,17}$ Berbeda dengan Hasratna, pengadaan obat dilakukan melalui tender terbuka, penunjukan langsung dan pembelian langsung (sistem e-katalog). ${ }^{16}$

Pendistribusian Sediaan Farmasi dan Bahan Medis Habis Pakai merupakan kegiatan pengeluaran dan penyerahan Sediaan Farmasi dan Bahan Medis Habis Pakai secara merata dan teratur untuk memenuhi kebutuhan sub unit/satelit farmasi Puskesmas dan jaringannya. ${ }^{3}$ Tujuannya adalah untuk memenuhi kebutuhan Sediaan Farmasi sub unit pelayanan kesehatan yang ada di wilayah kerja Puskesmas dengan jenis, mutu, jumlah dan waktu yang tepat. Sub-sub unit di Puskesmas dan jaringannya antara lain: (1) Sub unit pelayanan kesehatan di dalam lingkungan Puskesmas; (2) Puskesmas Pembantu; Puskesmas Keliling; (4) Posyandu; dan Polindes.

Pendistribusian ke sub unit (ruang rawat inap, UGD, dan lain-lain) dilakukan dengan cara pemberian Obat sesuai resep yang diterima (floor stock), pemberian Obat per sekali minum (dispensing dosis unit) atau kombinasi, sedangkan pendistribusian ke jaringan Puskesmas dilakukan dengan cara penyerahan Obat sesuai dengan kebutuhan (floor stock). ${ }^{3}$

Pendistribusian obat di Puskesmas Kota Jambi sudah berjalan dengan baik, didistribusikan setelah penanggungjawab obat menerima obat di Instalasi Farmasi Kota/Provinsi dan mengecek permintaan obat sesuai dengan LPLPO, dimana setiap unit pelayanan kesehatan di wilayah kerja Puskesmas mengantarkan data permintaan obat yang mereka butuhkan setiap tiga bulan ke penanggungjawab gudang obat Puskesmas, setelah itu nanti didistribusikan ke unit-unit kemudian dicatat dalam kartu stok. Obat yang diantarkan yang mendekati tanggal kadaluarsa diberitahukan kepada unit-unit agar digunakan segera. ${ }^{19,20,21,22}$ 
Pengetahuan responden tentang penggunaan obat meliputi kegiatan yang menetapkan ruang pelayanan obat dan membuat daftar perlengkapan peracikan obat, menyiapkan obat dan membuat daftar perlengkapan peracikan obat, menyiapkan obat dan menyerahkan obat, memberikan informasi obat dengan memperhatikan etika pelayanan obat. ${ }^{23,24}$

\section{KESIMPULAN DAN SARAN}

Kinerja pengelola obat di Puskesmas Kota Jambi dipengaruhi oleh komitmen pemimpin tetapi tidak dipengaruhi oleh masa kerja dan pengetahuan petugas.

\section{DAFTAR PUSTAKA}

1. Kementerian Kesehatan RI. Undang-Undang Republik Indonesia Nomor 36 Tahun 2009 tentang Kesehatan, Departemen Kesehatan RI, Jakarta. 2009.

2. Kementerian Kesehatan RI. Peraturan Pemerintah Republik Indonesia Nomor 51 Tentang Pekerjaan Kefarmasian, Jakarta. 2016.

3. Kementerian Kesehatan RI. Peraturan Menteri Kesehatan Republik Indonesia Nomor 74 Tentang Standar Pelayanan Kefarmasian di Puskesmas, Jakarta. 2009.

4. Direktorat Jenderal Pengawasan Obat dan Makanan. Pedoman Teknis Pengelolaan Obat Untuk Unit Pelayanan Kesehatan Kabupaten/Kota. Departemen Kesehatan RI, Jakarta, 2000.

5. Sriana A., dkk. Kemampuan petugas menggunakan pedoman evaluasi pengelolaan dan pembiayaan obat. Puslitbang farmasi dan obat tradisional, badan litbang kesehatan. Majalah Ilmu Kefarmasian, Vol. II No.2 Agustus 2005. 2002.

6. Dewi, AG. Upaya Peningkatan Kinerja Perawat dalam Pengisian Berkas Rekam Medis Rawat Inap Melalui Analisis Faktor Individu dan Faktor Sistem Manajemen : Studi Kasus di RSUD Kabupaten, (Tesis) Pascasarjana Univesitas Airlangga, Surabaya : Airlangga University Library, 2006.

7. Mursyidah. Analisis Seleksi Obat di Dinas Kesehatan Kabupaten Malang Melalui Metode Serviced Based. Post Graduate Airlangga University, 2005 library@unair.ac.id.

8. Purwanto S. Analisis Manajemen Logistik Obat di Puskesmas Kabupaten Sidoarjo, Post Graduate Airlangga University, 2008 library@unair.ac.id.

9. Ilyas, Y. Kinerja: Teori Penilaian dan Penelitian, Jakarta: FKM UI, IQ, Jakarta PT. Gramedian Pustaka Utama, 1999.

10. Ilyas, Yaslis. 1999. "Determinan Kinerja Dokter Puskesmas Kasus : Dokter Pegawai Tidak Tetap (PTT)", Jurnal FISIP UI Dep. Ilmu Administrasi, Depok.

11. Nila, Budiwarni. "Faktor-faktor yang berhubungan dengan kinerja petugas pengisi formulir LPLPO Puskesmas di Kabupaten Karawang", Tesis UI, 1997.

12. Husnaini, "Faktor-faktor yang berhubungan dengan kinerja petugas pengelola obat puskesmas dalam mengelola laporan pemakaian dan lembar permintaan obat (LPLPO) di kabupaten Padang Pariaman dan Agam propinsi Sumatera Barat", Tesis UI, 2001.

13. Effendi, M. "Faktor-faktor yang berhubungan dengan kualitas LPLPO Puskesmas se-Kabupaten Kapuas Hulu Tahun 1999-2000", Tesis UI, 2001.

14. Fitria. "Evaluasi Kinerja Pengelolaan Obat di Puskesmas Kabupaten Bungo, Jambi”. 2018.

15. Rismalawati, dkk. "Studi Manajemen Pengelolaan Obat di Puskesmas Lawa Kabupaten Muna Barat Tahun 2015", Fakultas Kesehatan Masyarakat Universitas Halu Oleo. 2015.

16. Hasratna, dkk. "Gambaran Pengelolaan Persediaan Obat di Instalasi Farmasi Rumah Sakit Umum Daerah Kabupaten Muna Tahun 2016”. Fakultas Kesehatan Masyarakat Universitas Halu Oleo. 2016.

17. Nurniati, L. "Studi Tentang Pengelolaan Obat di Puskesmas Buranga Kabupaten Wakatobi Tahun 2016". Fakultas Kesehatan Masyarakat Universitas Halu Oleo. 2016.

18. Kobandaha, F. dkk. "Analisis Manajemen Pengelolaan Obat di Puskesmas Wenang Kota Manado". 2016.

19. Husnawati, dkk. "Sistem Pengelolaan Obat di Puskesmas di Kecamatan Rambah Samo Kabupaten Rokan Hulu-Riau”, Vol. 13 No. 01. 2016.

20. Renaldi, R., Nanda, D. "Manajemen Pengelolaan Obat di Puskesmas Limapuluh Kota Pekanbaru Tahun 2017", Menara Ilmu Vol. XI Jilid 1 No. 78 November 2017. 2017.

21. Quick, J.D, Hogerzeil, H.V., Rankin, J.R., Dukes, M.N.G., Laing, R., Garnett, A., O'Connor, R.W., Managing Drug Supply (2rd ed), Kumarian Press. 1997.

22. Peters, D., Drug Management Cycle, Baltimore Maryland, John Hopkins, University. 2006.

23. Fitria. "Evaluasi Kinerja Pengelolaan Obat di Puskesmas Kabupaten Bungo, Jambi", Electronic Theses and Dissertations (ETD) Gadjah Mada University. 2018

24. Rambu. "Pengaruh Karakteristik Individu dan Motivasi Terhadap Kinerja Pengelola Obat Puskesmas di Kabupaten Sumba Timur", Tugas Akhir Program Magister (TAPM), Universitas Terbuka, Jakarta. 2015. 


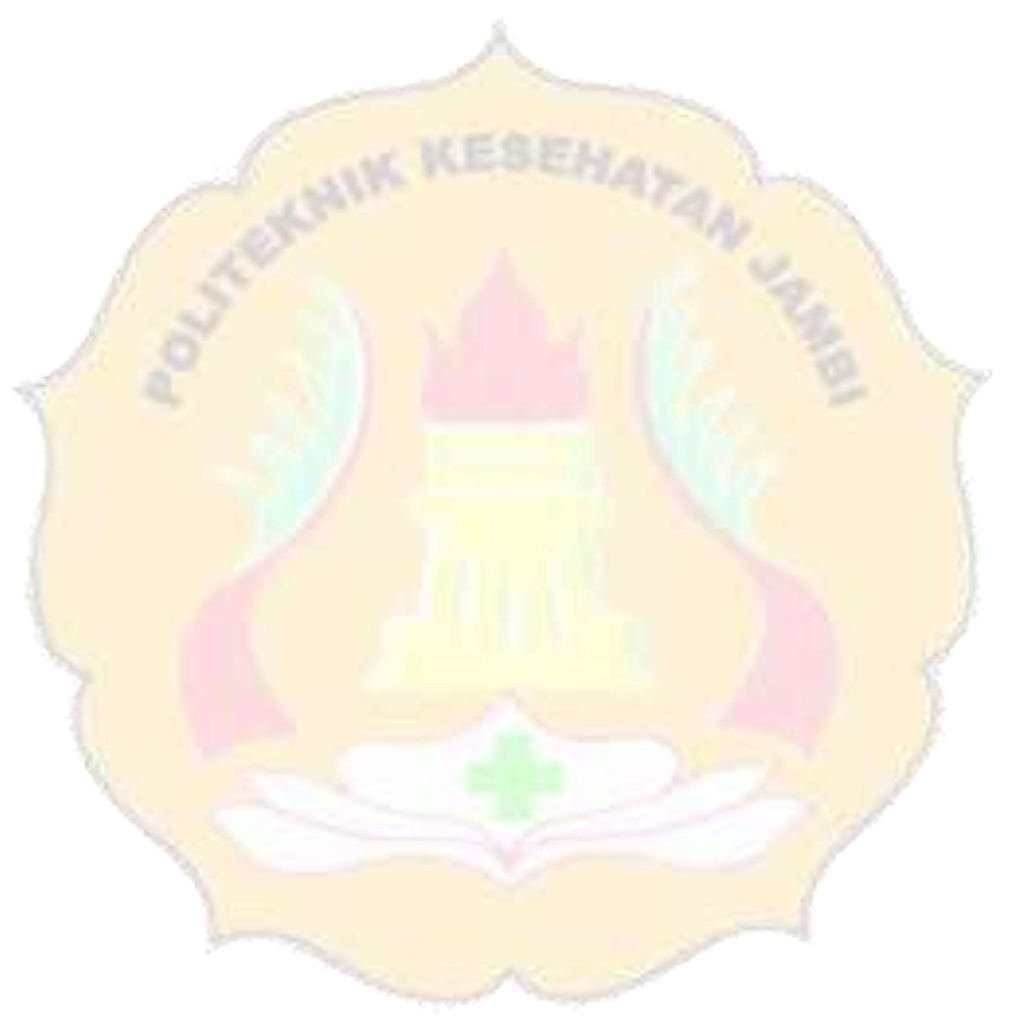


Diterima:

Direvisi:

Disetujui:
Jurnal Bahana Kesehatan Masyarakat (Bahana of Journal Public Health) Vol 3 No 2 p-ISSN: 2580-0590/ e-ISSN: 2621-380X doi: https://doi.org/10.1007/s40496-015-0047-x

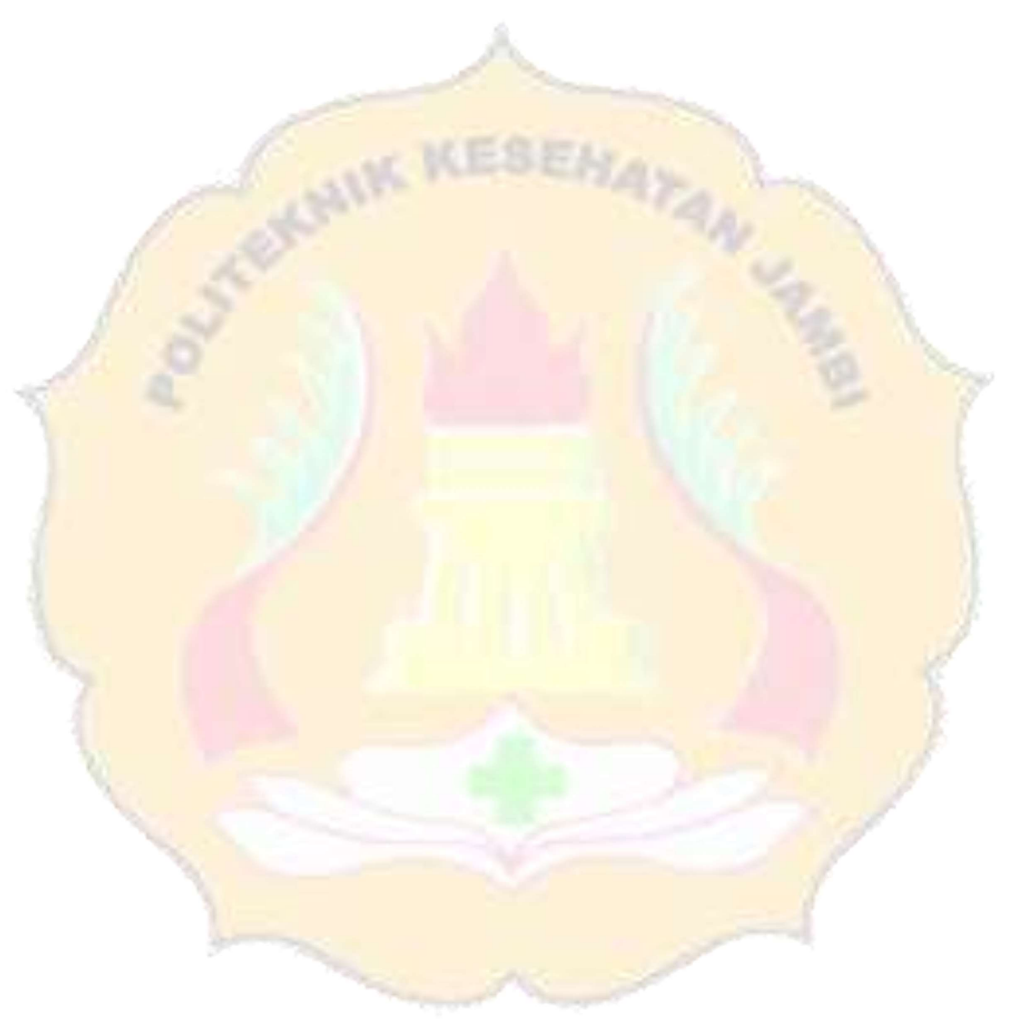

